\title{
A construção da subjetividade feminina brasileira em Gabriela, cravo e canela na passagem do séc. XIX para o séc. $\mathbf{X X}$
}

Joana d'Arc Martins Pupo

\begin{abstract}
$\overline{\text { Resumo:Este artigo tem como objetivo analisar as representações de gênero na obra Gabriela, cravo e }}$ canela, de Jorge Amado, especificamente nas personagens Ofenísia, Glória, Malvina e Gabriela, uma vez que são suas histórias que estruturam o romance e que marcam o desenrolar dos deslocamentos identitários femininos na narrativa na passagem do final do séc. XIX para o início do séc.XX. Ao analisarmos os discursos que atravessam essas personagens, tomaremos as epígrafes musicais que abrem cada capítulo como chaves interpretativas para as mesmas, concluindo que, apesar de não se tratar de uma obra de cunho puramente feminista, ainda assim, o romance amadiano pode ser visto como uma clara ilustração da construção da subjetividade da mulher brasileira e da construção social do conceito de gênero.

Palavras-chave: feminismo; gênero; representação; subjetividade; identidade.

Abstract. This article aims at analyzing the gender representations in Gabriela, cravo e canela, by Jorge Amado, in particular the characters Ofenísia, Glória, Malvina and Gabriela, as their stories structure the novel and mark the development of the female identity displacements in the literature from the end of the $19^{\text {th }}$ century to the beginning of the $20^{\text {th }}$ century. In order to analyze the discourses which permeate these characters, we will take into consideration the musical epigraphs of each chapter as keys to our interpretation. Even though Gabriela, cravo e canela is not a feminist literary work, Amado's novel can be considered a clear representation of the construction of the subjectivity of Brazilian women and of the social construction of the concept of gender.

Keywords. Feminism; Gender; Representation; Subjectivity; Identity.
\end{abstract}

Introdução

Com a publicação de Gabriela, cravo e canela em 1958, grande parte da crítica literária entendeu que aí se encerrava a fase em que um forte teor político-social marcava as obras de Jorge Amado, iniciando o autor uma segunda fase, em que as lutas de classe atenuam-se e as representações femininas ganham destaque. Por esta mudança de foco, de um lado, o autor foi, inicialmente, acusado de ter optado pelo fácil, pelo a-político, pelo pitoresco e Gabriela, cravo e canela chegou a ser avaliado como um romance picaresco. Entretanto, do ponto de vista da recepção e considerando o que nos ensina *Professora Ms. Joana d'Arc Martins Pupo - Universidade Estadual de Ponta Grossa - UEPG - E-mail:
jopupo@uol.com.br 
Jauss (1994) que "tanto em seu caráter artístico quanto em sua historicidade, a obra literária é condicionada primordialmente pela relação dialógica entre literatura e leitor", acreditamos que as leituras contemporâneas, influenciadas pelas perspectivas pós-modernas, pelos estudos culturais, bem como pela crítica feminista, podem contribuir para o estudo do romance em questão, sobretudo no que diz respeito à raça, gênero, nação, sexo na literatura brasileira. Gabriela, cravo e canela pode ser lida como uma obra que se ocupa em profundidade da representação do gênero, retratando a possibilidade de uma constituição da subjetividade feminina através da emancipação do desejo sexual, bem como uma crônica de costumes, que retrata também a nação e a sociedade brasileiras, veiculadoras do discurso masculinista do patriarcado. É neste campo de tensões identitárias que se dá o romance e dessa perspectiva, a nossa leitura.

Assumimos, neste trabalho, que, Gabriela, cravo e canela não é uma obra feminista, mas que pode ser compreendida como uma representação da subjetividade feminina dentro das condições sócio-históricas que aí se fazem representar. Propomo-nos observar a construção de algumas subjetividades femininas, a partir do próprio texto de Jorge Amado e, de posse de algumas reflexões propostas pela crítica feminista.

Nossa escolha teórica decorre do fato de que, desde suas primeiras teses, a crítica feminista tomou para si a tarefa de denunciar a opressão e a discriminação das mulheres, e ainda pelo fato de que as teorias feministas pós-modernas, ao trazerem o gênero como categoria de análise, colaboraram enormemente para o deslocamento do conceito iluminista do sujeito cartesiano, de "identidade fixa e estável" para a concepção das "identidades abertas, contraditórias, inacabadas, fragmentadas, do sujeito pós-moderno" (HALL, 2005 , p.46). A cada nova abordagem no decorrer da história do movimento feminista, diferentes aspectos na constituição das subjetividades foram iluminando o caminho das gerações feministas seguintes em busca da desestabilização de certas crenças sobre a(s) mulher(es) e em busca do desencobrimento de práticas culturais criadas e naturalizadas através dos discursos hegemônicos do patriarcado e do colonialismo para (de modos variados e, inúmeras vezes, invisíveis) perpetuar as mulheres na condição subalterna de subcidadãs. Privilegiaremos, neste trabalho, a confluência de diversas perspectivas feministas e não uma em particular. Preferimos preservar a pluralidade constitutiva de seus aportes, um dos maiores méritos do movimento feminista.

Por se tratar, principalmente, de um romance cuja estrutura narrativa se constrói a partir da história de várias e variadas mulheres - onde o plural 
A construção da subjetividade feminina brasileira em Gabriela, cravo e canela ...

possa aqui talvez adquirir um significado mais amplo, em vez de, simplesmente, denominar 'várias da mesma espécie' - mesmo que a narração ocorra através "de um olhar masculino e colonizado, inclinado ao exótico." (DUARTE, 2002), é que Gabriela, cravo e canela revela-se uma obra potencialmente rica para ser explorada no que se refere às representações identitárias.

Em Gabriela, uma infinidade de personagens tanto femininas quanto masculinas representa a sociedade brasileira da perspectiva da diversidade étnica e social da Bahia, tomada como microcosmo da sociedade multicultural e multirracial brasileira, onde o mito da democracia racial prevê o convívio harmonioso entre os diferentes.

Entre as mulheres, à parte as quatro personagens que dão nome aos capítulos, há ainda as esposas oficiais, devotadas e devotas e bem adaptadas mães de família; as filhas, aos moldes das mães, bem conformadas a seus destinos; há as raparigas, prostitutas de um homem só (mulheres pobres que se tornam amantes dos coronéis para serem sustentadas e poderem, então, usufruir do conforto e das regalias exclusivas das classes altas); há as prostitutas dos cabarés - prostitutas de todos.

Neste trabalho, percorreremos a construção das representações femininas, especificamente, nas personagens Ofenísia, Glória, Malvina e Gabriela, uma vez que suas histórias é que servem para marcar o desenrolar dos deslocamentos subjetivos femininos na narrativa. Ao analisarmos os discursos que atravessam essas personagens, tomaremos as epígrafes musicais, que abrem cada capítulo, como chaves interpretativas para as mesmas.

O romance de Jorge Amado é dividido em duas partes ("Um brasileiro das Arábias" e "Gabriela, cravo e canela"). O título da primeira delas sugere de imediato a importância de Nacib e de sua identidade construída na fronteira entre duas culturas. Somente esse brasileiro nascido na Siria, [que] sentia-se estrangeiro diante de qualquer outro prato não baiano, à exceção do quibe (AMADO, p.345) poderia não ter matado a mulher adúltera, não por covardia, não porque não tinha dado tempo, porque não era sua "natureza". Para o representante da modernidade, Mundinho Falcão, Nacib ao não matar Gabriela agira como um parisiense, um londrino, um estrangeiro. Eterno estrangeiro cujo pertencimento àquela terra jamais poderia ser pleno. Nacib se encontra entre "aquelas formações de identidade que atravessam e intersectam as fronteiras naturais, compostas por pessoas (...) devem aprender a habitar, no mínimo, duas identidades, a falar duas linguagens culturais, a traduzir e a negociar entre elas." (HALL, 2005,p.89) 
Entretanto, o que mais nos interessa para este trabalho é a subdivisão das duas partes nos quatro capítulos, O langor de Ofenísia; A solidão de Glória; O segredo de Malvina e; finalmente, O luar de Gabriela, e a apreciação das epígrafes dedicadas a cada uma dessas mulheres na forma de uma composição musical e que antecipam suas posições identitárias, através da antecipação de seus destinos. $O$ valor destes textos poéticos não reside em seus aspectos estritamente estéticos - as formas utilizadas por Jorge Amado não trazem formalmente a preocupação de adequação às características estruturais tradicionais dessas modalidades musicais -, mas na possibilidade de, através desta estruturação, lermos o romance amadiano como uma história de resistência do desejo feminino em direção à construção da subjetividade feminina brasileira na passagem do séc. XIX para o modernismo do início do séc.XX.

O tema da opressão feminina, que permeará toda a narrativa, é antecipado logo no início, pelo narrador (de olhar nitidamente masculino), que chama a atenção do leitor para o fato da história de amor entre Gabriela e Nacib ter se iniciado exatamente no dia em que o Cel. Jesuíno Mendonça matou Dona Sinhazinha, sua "legítima" esposa, por tê-la surpreendido na cama com seu amante dentista. Desse modo, o leitor toma conhecimento que se mantém, em Ilhéus, em meados da década de 20, a antiga prática dos tempos coloniais: “... a própria lei permitia que 'achando o homem casado sua mulher em adultério, licitamente poderá matar assim a ela como o adúltero"' (ARAÚJO, Emanuel, In: DEL PRIORE, 2000, p.59). Entretanto, Dona Sinhazinha, tal qual Glória e Gabriela, não hesitou arriscar-se mas, como Ofenísia, pagou com a vida a assunção de seu desejo.

Cada qual a seu modo, as personagens centrais que estruturam o romance ao não se submeterem, plenamente, ao jugo do discurso patriarcal, contribuíram para a construção de novas alteridades naquela sociedade.

Já na abertura do capítulo 1, O Langor de Ofenísia, encontramos a advertência de que apesar de pouco aparecer, a personagem Ofenísia "nem por isso é menos importante. "(AMADO, p.3), razão que buscaremos esclarecer no decorrer desta parte do artigo.

Ofenísia Ávila, fidalga portuguesa, ancestral distante do Doutor, viveu uma história de amor platônico com o Imperador Dom Pedro II, mas impedida pelo irmão de ir atrás desta paixão, Ofenísia morreu "tísica e virgem, saudosa das barbas reais." (AMADO, p.25). Ofenísia é, claramente, a representação da mulher romântica, herança do patriarcado do século XIX. Lânguida, cuja frágil compleição revela sua debilidade, traz, em si as características que se 
A construção da subjetividade feminina brasileira em Gabriela, cravo e canela ...

impunham artificialmente às mulheres através das práticas sociais que restringiam os movimentos das iaiás, domesticavam seus corpos e suas percepções de si mesmas. Podemos reconhecê-la em algumas das descrições que Gilberto Freire faz em Sobrados e Mucambos:

A extrema diferenciação e especialização do sexo feminino em 'belo sexo'e 'sexo frágil', fez da mulher de senhor de engenho e de fazenda e mesmo da iaiá de sobrado, no Brasil, um ser artificial, mórbido. Uma doente, deformada no corpo para ser a serva do homem e a boneca de carne do marido. (FREIRE, 2006, p.208)

Tendo sua escolha amorosa recaído sobre o próprio imperador, Ofenísia vê-se privada talvez da única chance para que uma fidalga pudesse escapar "[d] o critério patriarcal e endogâmico de casamento." (FREIRE, p.246), e se casar com um homem de sua escolha. Jamais o Imperador D. Pedro II poderia recorrer ao 'rapto consentido', prática que havia se tornado comum no século XIX, e que funcionara como estratégia para que muitas iaiás se casassem com o homem de sua predileção sexual. Em vez disso, Ofenísia morrerá de amor, mas também de tuberculose, doença que, na época colonial, atingia em maior grau as mulheres tanto por causa dos hábitos alimentares impróprios, que lhes eram incentivados através da mitificação poética da "virgem pálida" que se alimentava apenas de "... caldinhos de pintainho, água-de-arroz, confeitos..." (FREIRE, p.232), como por causa do uso de vestimenta inadequada no "arrocho do espartilho" que lhes "perturbava 'o jogo respiratório das costellas e diaphragma ...". Morre, então, "[d]O mal [que] não era, pois, dos 'ares'e sim da falta de adaptação do trajo da classe alta ao clima tropical." (FREIRE, p.238)

A epígrafe musical que abre o capítulo $O$ Langor de Ofenisia consiste de um rondó, composição lírica originariamente francesa e, em cuja letra amadiana encontramos a representação do espírito da vida aristocrática, marcada pela valorização da elegância exterior, da frivolidade e do ócio, tipicamente atribuído às mulheres brancas de condição nobre no período colonial: Ofenísia na varanda/ na rede a se balançar/O calor e o leque/ a brisa doce do mar/ mucama no cafuné./ Já ia fechar os olhos/O monarca apareceu (...)

Este tipo de poema lírico, que por volta do final do século XVIII, serviu para que os compositores pudessem permitir que as personagens expressassem seus sentimentos mais profundos - o que Ofenísia faz sem o menor pudor -, 
traz no nome a idéia de circularidade: rondeau (do latim, rotundus), "redondo, em forma de roda" (MOISÉS, p.411), e movimentando-se nesta circularidade será somente já quase ao final do romance que Ofenísia retornará à cena por ocasião da publicação de sua história pelo Doutor Pelópidas de Assunção Ávila, "A história da família Ávila e da cidade de Ilhéus" (AMADO, p.309).

"Da nobre Ofenísia à plebéia Gabriela", a narrativa desliza por sobre os trilhos do progresso, trazendo de passageiro, na transubstanciação da personagem Ofenísia, um pouco da história das mulheres no Brasil agora com o deslocamento dos padrões externos eurocêntricos impostos às mulheres brancas da nobreza ou das classes mais altas na época colonial à valorização da mulher mestiça, idealizada física e culturalmente, o locus, por excelência, da nacionalidade brasileira, pois na obra do Doutor Pelópidas, Ofenísia ganha qualidades físicas semelhantes às de Gabriela.

Compreendemos, então, a importância de Ofenísia, referida no início na narrativa, como a "precursora da idéia do amor livre no Brasil" (p. 309). Bem antes de Gabriela, esta dama da nobreza ousara desafiar os valores morais de sua época ao declarar-se disposta a ocupar um lugar que era totalmente interdito, principalmente, às mulheres de sua estirpe social. Ofenísia antecipa-se à Gabriela e lhe serve de contraponto no que diz respeito às representações de raça (branca x mulata), nacionalidade (portuguesa $\mathrm{x}$ brasileira) e classe social (rica x pobre), que tradicionalmente serviram para diferenciar e separar os sujeitos cultural e socialmente. Entretanto, ao ganhar contornos híbridos, a síntese Ofenísia-Gabriela, além de configurar a miscigenação da sociedade brasileira, oferece-se à interpretação da universalidade da condição do humano feminino.

O segundo capítulo do romance abre com o título "A solidão de Glória" (na sua janela a suspirar). A personagem e sua janela "amaldiçoada" já haviam sido mencionadas logo no início do romance. Em seguida, o leitor aproxima-se da representação de Glória através da epígrafe musical, que lhe é dedicada na forma de um lamento. O lamento, de acordo com Massaud Moisés, tem origem, na Grécia Antiga, como uma modalidade de elegia, designando, entre os gregos, as ladainhas ou cantos fúnebres. Entretanto, ressalta o autor, nestes cantos, "a dor expressa se fazia acompanhar de um sentimento de admiração pelos mortos." (MOISÉS, 2004, p.451) Deste modo, o threnos (no grego 'lamentação') associa-se, por sua composição musical e caráter literário, à arte culta do hino. Não podemos deixar de associar esta referência ao hino 
A construção da subjetividade feminina brasileira em Gabriela, cravo e canela ...

elogioso ao nome da personagem: Glória, a gloriosa, a rapariga do coronel Coriolano Ribeiro, digna de ser cantada, louvada, mas que, mesmo estando guardada como objeto de desfrute para um único senhor, serve "à tarde na janela, os robustos seios empinados como uma oferenda aos passantes" (grifo meu, AMADO, p.87).

Glória representa, dos tempos coloniais,

"as mulheres jovens, sem status ou sem bens e que não haviam conseguido casamento numa terra de mercado matrimonial estreito, [que] encontravam num homem mais velho, mesmo sendo casado, o amparo financeiro e social de que precisavam. [...] Ser amásia ou cunhã de um homem importante implicava formas de sobressair-se junto à população e galgar um status econômico, que ela não possuiria de outra forma." (FALCI, apud PRIORE, 2000, p.269)

Ao mesmo tempo adorada e desprezada, a sociedade mantém com a personagem a relação irresoluta de reconhecimento e negação que sempre serviu na sociedade patriarcal para manter a estrutura que reservava as atividades sexuais das esposas oficiais, brancas, à função exclusiva da procriação, a única condizente com a valorização da 'pureza' imposta às mulheres no estabelecimento da dicotomia que buscava diferenciar, o máximo possível, os homens, em sua virilidade, das mulheres.

Em total contraste com a situação da nobre Ofenísia, é a posicionalidade de Glória _ moça, mulata e pobre _, dentro da estrutura político-social do sistema patriarcal, que lhe garante as condições para ocupar o lugar de concubina.

Restrita ao espaço doméstico, paradoxalmente sem diferença em relação às mulheres burguesas da época, Glória provoca de sua janela a adoração dos homens, que não ousam mais do que desejar a mulata de "rosto moreno queimado, de lábios carnudos e ávidos, de olhos entronados em permanente convite" (AMADO, p.88). A personagem é, inegavelmente, representada na já popular imagem sexualizada e racializada da mulata, reconhecida, desde Gilberto Freyre, como preferência nacional para a satisfação sexual do homem branco naquela sociedade, onde "a exclusividade de casamentos endogâmicos dentro do grupo branco e relações fugazes ou uniões de cunho consensual e informal entre homens brancos e mulheres negras" (MISKOLCI \& CAR- 
VALHO, 2006) mantinha a dominação hierárquica tanto étnica quanto entre os gêneros.

Através do lamento de Glória, tomado aqui em sua expressiva ambigüidade, pode-se conhecer a maldição que a envolve, originária de sua condição de rapariga, mas da qual Glória não deixa de se queixar. Dando-lhe acesso aos bens materiais mais luxuosos, "O coronel Coriolano [que] não era homem para brincadeiras" (AMADO, p.89), ao mesmo tempo em que lhe propicia um estilo de vida equivalente ao das mulheres da elite, a mantém irremediavelmente prisioneira em sua solidão.

Glória, em sua lamentação, assume para si o discurso de enaltecimento das qualidades físicas e sensuais da mulata simultaneamente reforçando o "mistério" em que se envolvia essa sensualidade. Ao aderir às categorias construídas do ponto de vista dos dominantes, vendo-se através dos olhares dos homens brancos, e se oferecer à classificação de "misteriosa", que embute em si os antecedentes mitológicos do eterno feminino, relacionando as mulheres à transcendência, à arte da magia e da sedução e do mistério, Glória naturaliza a relação de dominação masculina e interdita em si a consciência de ser um produto social, construído simbolicamente através do discurso hegemônico falocêntrico.

Entretanto, na narrativa, Glória transcenderá os limites próprios de sua condição. Mesmo confinada em sua infinita solidão, Glória deixa-nos entrever, em seu queixume, sua resistência à privação do direito de amar. Em seu lamento, Glória insiste em perguntar quem ousará se queimar em seu calor, revelando, na inconformidade de sua solidão, a disposição de se arriscar, tal qual Dona Sinhazinha, Ofenísia, Malvina e Gabriela, para se ver realizada enquanto sujeito de seu desejo.

É também de sua janela que Glória tentará o professor e poeta Josué, que depois de desiludir-se em relação ao amor não correspondido de Malvina, atreve-se a deitar com Glória. Mas, mais uma vez, equivocado, nos seus (pré) conceitos em relação ao que querem as mulheres, Josué surpreende-se ao ver fracassados "seus planos: com ela [Glória] de braço dado na rua, afrontando a sociedade, morando os dois no quartinho sobre o Cinema Vitória, numa pobreza ascetas mas milionários de amor..." (p.224) Entretanto, é Glória quem faz a escolha: recusa-se a abandonar a vida de luxo e regalias de mantida e opta por ter "as duas coisas: o amor e o conforto, Josué e Coriolano." 
A construção da subjetividade feminina brasileira em Gabriela, cravo e canela ...

A história de Glória serve para sermos introduzidos na lei específica para traição de raparigas, que não pagam com a morte o adultério descoberto, senão que sofrendo apenas um castigo aplicado aos amantes. De certo modo, a representação feminina de Glória prepara o leitor para a de Gabriela. Enquanto Ofenísia é a representação feminina puramente inspiradora, Glória, beneficiada pelo andamento do progresso em Ilhéus, torna-se uma possibilidade concreta de realização de novos paradigmas de identidade feminina em meados da década de 20 .

A segunda parte do romance "Gabriela, cravo e canela" inicia com o terceiro capítulo "O segredo de Malvina (nascida para um grande destino, presa em seu jardim). Primeiramente, Malvina representa a mulher jovem, branca e rica de família tradicional, cuja posição social a predestinaria a um casamento endogâmico, cuja escolha se daria certamente pelas influências familiares e, à assunção dos papéis tradicionais de mãe e esposa.

A epígrafe musical, que inicia a história de Malvina, é uma de cantiga de ninar. As cantigas de ninar, formas populares muito antigas de origem indefinida, muitas vezes, associam paradoxalmente o embalo calmante do acalanto a temas povoados de criaturas que costumam despertar o terror nas crianças - supostamente também como uma forma de educá-las através das ameaças veladas que lhes são cantadas. Assim é o sonho de Malvina nesta composição: misto de realização de desejo e pesadelo, trazendo em si as representações dos medos inconscientes e anseios da personagem: Dorme, menina dormida/ teu lindo sonho a sonhar/No teu leito adormecida/ partirás a navegar./Estou presa em meu jardim/ com flores acorrentada./Acudam! vão me afogar (...) Acudam! vão me casar/ numa casa me enterrar/na cozinha a cozinhar(...)

Da lógica própria do sonho, encontramos na letra da cantiga, a presença polifônica das vozes de Malvina, que implora por socorro; e uma outra voz que, ao mesmo tempo em que insiste, na repetição constante do refrão "Dorme, menina dormida, teu lindo sonho sonhar. No teu leito adormecida partirás a navegar", parece permanecer indiferente aos apelos da personagem.

O tema do pesadelo de Malvina é a condenação da mulher aos desígnios da sociedade patriarcal. São apelos para que não lhe consintam destino semelhante ao de sua mãe, a quem está determinada a não imitar: "Infeliz como vocên não serei, minha mãe." (AMADO, p.217). A mãe é a representação da mulher submissa, anulada pelo discurso patriarcal, sem voz, e que se submetendo totalmente ao discurso misógino do marido, encontra completamente alijada sua subjetividade. 
$\mathrm{Na}$ ambigüidade onírica do acalanto, Malvina se embala na oscilação entre um bem-estar, proporcionado por este ser zeloso, que vela a possibilidade da realização de seu desejo de liberdade, e a insinuação da possibilidade da morte _ a morte da subjetividade feminina, decorrente da submissão às imposições da ordem hegemônica masculinista.

O refrão, a repetir "No teu leito adormecida partirás a navegar", desempenha também a função de um aviso _ como em um sonho premonitório. E na indefinição típica dos sonhos, a sobreposição do sentido indica ou a partida para longe, onde possa se emancipar, ou a partida para a morte no mar. Assim, ao mesmo tempo, em que o refrão reforça a idéia do isolamento de Malvina (de certo modo, semelhante à solidão de Glória), ao considerarmos o desfecho de sua história, reconheceremos aí a duplicidade que insinua também uma vida futura de emancipação sob novas alteridades.

Malvina também viveu as ilusões construídas através da visão do amor romântico e, como muitas outras mulheres criadas sob a égide deste discurso, acreditou que a possibilidade da subjetivação feminina só pudesse ser alcançada através da experiência relacional com o outro masculino: Quem seja ele _que importa?/ moço pobre ou moço rico/bonito, feio, mulato (...)

Entretanto Malvina já é filha da modernidade, nascera respirando o ar das mudanças políticas, sociais e econômicas das primeiras décadas do século XX. É mais uma representação de mulher-leitora na literatura e é por caracterizar-se como uma mulher que pôde, devido a sua condição social e cultural, ter acesso ao conhecimento, que também servirá como porta-voz de Ofenísia, Glória e Gabriela, a quem, como a uma grande massa de mulheres, não foi dado o direito a uma educação formal ${ }^{1}$.Malvina, enquanto leitora dos romances de Eça de Queiroz, Aluízio de Azevedo será capaz de, ao mesmo tempo em que se revela consciente dos obstáculos impostos por ter que "falar numa cultura em que ser mulher é falar a língua do outro, isto é, ficar em silêncio" (AZERÊDO, 2007, p.31), tomar a palavra e se impor como sujeito.

Depois de ter enfrentado a sociedade, o autoritarismo e a violência paternos e ter se decepcionado diante da omissão e covardia de Rômulo, engenheiro com quem acreditara poder fugir, vacila, como na indefinição da cantiga de ninar, entre a vida e a morte real: "Malvina esperava no alto dos penedos. Em baixo, as ondas chamavam.” (AMADO, p.221)

\footnotetext{
${ }^{1}$ Lamentavelmente, dados recentes da UNESCO apontam que dos 781 milhões de pessoas analfabetas no mundo, ainda hoje, dois terços são mulheres. (Ver: http://www.unesco.org.br/) 
A construção da subjetividade feminina brasileira em Gabriela, cravo e canela ...

Entretanto, a consciência crítica desperta-a para a possibilidade da configuração de uma nova ordem social, fazendo com que perceba que estivera apenas convencida dos valores machistas que procurara arduamente combater e que assumira como seu o discurso que a escravizava.

Na narrativa de Gabriela, cravo e canela, a história das mulheres brasileiras chega, com a determinação de Malvina, à modernidade do início do século XX, com todos os avanços e recuos, com todas as lutas e resistências, e contradições femininas que continuam a nos desafiar na contemporaneidade por estarmos mergulhadas em uma cultura dominada por uma linguagem falocêntrica.

O último verso de sua cantiga "Partirei pra me encontrar para jamais partirei." sugere uma idéia de incompletude sobre o que mais pudesse ter sido imposto às mulheres no passado, se algumas, como Malvina, não tivessem tido a coragem de se opor à hegemonia masculina, suspendendo simultaneamente qualquer determinismo futuro. Não importa responder ou completar, Malvina partiu para a incerteza do devir feminino, o que iguala a condição de sua constituição subjetiva a de qualquer outro sujeito humano, por que constituída na e pela linguagem.

"O luar de Gabriela (talvez uma criança, ou o povo, quem sabe?)" é o quarto e último capítulo do romance, cuja epígrafe musical é intitulada "CANTAR DE AMIGO DE GABRIELA". Segundo MOISÉS (2004, p.67) cantar é outro termo utilizado para a canção ou cantiga, composições típicas da Idade Média que associavam o poema à melodia. As cantigas eram classificadas, da perspectiva de seus conteúdos, em: de amor, de amigo, de escárnio, de maldizer, entre outras. No entanto, à Gabriela o autor, sugestivamente, dedica uma cantiga de amigo, pois esta se caracteriza por expressar " $a$ coita (mágoa) amorosa da moça do povo, [ao contrário da cantiga de amor na qual o trovador endereçava-se a uma moça aristocrática] e se dividia, conforme o lugar e as circunstâncias em que se armava o quadro sentimental, em pastorela*, barcarola*, bailada*, cantiga de romaria*, alba*” MOISÉS (2004, p.67-grifo meu).

$\mathrm{O}$ "Cantar de amigo de Gabriela" inclui-se, com algumas modificações, na categoria da pastorela, uma vez que neste tipo encontramos o "diálogo amoroso entre o trovador, ou cavaleiro, e a pastora, travado em ambiente campesino. Por vezes, participava uma terceira personagem, ojovem enamorado da pastora...” MOISÉS (2004, p.344). Porém, Jorge Amado, em 
vez de estabelecer o diálogo entre a pastora e o trovador, prefere estabelecê-lo entre o trovador e o enamorado, concordante com a narrativa, durante a qual Gabriela não terá muitas falas, sendo sempre mais falada, e na maioria das vezes, por personagens masculinas.

Já na abertura do capítulo, o autor aponta para a representação de Gabriela carregada de ambigüidade "(talvez uma criança, ou o povo, quem sabe?)" (AMADO, p.239 - grifo meu). Em uma narrativa lacunar, as indefinições sobre a identidade de Gabriela estarão presentes em diversos momentos, instigando uma leitura de descoberta das possibilidades de suas alteridades enquanto um sujeito do feminino. Teremos somente pequenas pistas de seu passado: da infância pobre; ficara órfã, e sem sobrenome, "aos cuidados" de uns tios tão miseráveis quanto ela; do fato de ter sido seu tio, quando ela era ainda uma menina, quem a iniciara sexualmente.

Podemos reconhecer nesta alusão do autor o significado da representativa diferença, de que temos conhecimento, entre as práticas de educação e iniciação sexuais que marcavam a vida das meninas e moças pobres daquelas das mulheres advindas das classes superiores. A precocidade e naturalização da experiência sexual das primeiras, mesmo que, na maioria das vezes, não se caracterizassem como práticas libertárias e igualitárias em relação aos homens, contrastavam enormemente com as fortes repressões impostas às mulheres da burguesia, para quem a virgindade era moeda de troca em casamentos endogâmicos que garantiriam a conservação e/ou ampliação do patrimônio familiar.

O fato da representação de Gabriela resultar em uma caracterização que oscila entre o determinismo e o livre-arbítrio, entre o naturalismo e a representação de uma mulher que assume uma atitude autônoma no que concerne a seu desejo, advém também do lugar em que esta ocupa na estrutural social brasileira representada na narrativa e, portanto, constituída (bem como interpretada) pelo discurso masculinista dominante daquele contexto histórico e cultural. Entretanto, a personagem também se projeta para além da esfera de uma "eva" idealizada - aspecto que mais se destacou na medida em que a personagem transformou-se em mito nacional_ para tornar-se a representação de uma mulher que, à margem das convenções sociais da sociedade ocidental capitalista, burguesa e católica, pode mover-se com mais espontaneidade, impulsionada pelos seus desejos pelas coisas simples: "Só desejava a campina, colher as flores do mato [...] Só desejava o amor dos homens para bem amar" 
A construção da subjetividade feminina brasileira em Gabriela, cravo e canela ...

Ainda, ao contrário das mulheres moldadas pelo romantismo que, tendo tomado como seus os valores veiculados pela linguagem androcêntrica, associavam compulsoriamente a vida sexual feminina à vivência do encontro amoroso, notadamente com um outro masculino, Gabriela não reconhece o amor como pré-requisito para a concretização da experiência sexual. E é em sua transgressão deste tabu que reside a maior incompreensão sobre sua identidade, causando grande aflição aos personagens masculinos que, ao se relacionarem com ela, assumem para si o direito de possuí-la para além dos momentos de desfrute passageiros que haviam compartilhado.

De sua inconformidade com a autonomia de Gabriela e da impotência a que sua involuntária ignorância lhe impunha, Clemente_sertanejo, homem do povo _ reproduz o discurso colonial misógino que marca a visão da mulher como ser infantil e inferior que pode e deve sofrer castigo pela mão masculina por não obedecer aos costumes e regras impostos pela sociedade patriarcal: "Nem sabia como responder-lhe, esquecia os argumentos, também os insultos, a vontade de bater-lhe para ela aprender que com um homem não se brinca." (AMADO, p.81) Também, Nacib apesar de sua representação como homem mais aberto às mudanças e sensível às questões femininas, temendo perder Gabriela para outro, equivocou-se ao casar-se com ela.

No deslocamento de sua alteridade, de Gabriela à Sra. Saad, Jorge Amado denuncia a distinção masculinista presente na atribuição de diferentes valores sociais às mulheres conforme os laços estabelecidos social e juridicamente, inapelavelmente tendo os homens como referência: como amante, Gabriela recebe presentinhos baratos; como esposa passa a merecer jóias verdadeiras. No "Cantar de Amigo de Gabriela", percebemos a distância entre o imaginário masculino a respeito do que quer a mulher e o desejo feminino. Nota-se o contraste entre o que Gabriela _ a moça do povo _ desejava e os signos aristocráticos que, de uma perspectiva masculina burguesa, a deveriam agradar e satisfazer: Palácio real lhe dei, um trono de pedrarias, sapato bordado a ouro, esmeraldas e rubis...".

Das vozes masculinas que se enunciam sobre Gabriela, é apenas João Fulgêncio, o livreiro, que alerta para o temperamento livre de Gabriela: “_ Tem flores, você já reparou? que são belas e perfumadas enquanto estão nos galhos, nos jardins. Levadas pros jarros, mesmo jarros de prata, ficam murchas e morrem.” (AMADO, p.234) e ainda, “... O único erro em toda essa história foi você ter casado com ela. Foi ruim pra você, pior para ela." 
(AMADO, p. 353) Será ele quem concluirá, já quase ao fim da narrativa, que "Não se pode explicar Gabriela".

No entanto, ao mesmo tempo em que não se pode explicar Gabriela, Jorge Amado projeta, na personagem, variadas concepções míticas já primitivamente associadas à mulher. Será através do próprio discurso patriarcal, presente no romance, que o autor colocará em evidência a natureza desta linguagem como uma ordem simbólica histórica e culturalmente construída pela sociedade patriarcal, sugerindo, desse modo, sua própria desconstrução e a conseqüente desestabilização das identidades, principalmente as femininas, que através dela estão constituídas.

Gabriela é signo de pureza, ingenuidade, transcendência, beleza, docilidade e compaixão ao mesmo tempo em que a sensualidade exacerbada da mulata, a quem '...., uma como permanentemente 'superexcitação sexual', que faria dela uma anormal; e do ponto de vista da moral européia e católica, uma grande e perigos a amoral" (FREYRE, 2006, p.743), a aproximaria da mulher feiticeira. Gabriela pode o que as outras não podem. Conseguiria qualquer coisa de qualquer homem que quisesse, como sugere Dona Arminda em relação a Nacib. Também, na imagem mítica da serpente, encontramos a caracterização da mulher traiçoeira: ela é a "cobra de vidro" que Clemente matou, partindo em três pedaços o corpo brilhante e esmagando-lhe a cabeça, porque era "bonita demais e só com isso fazia mal." (AMADO, p.329). Ainda proveniente dos arquétipos femininos, Gabriela traz o encantamento da sereia. E é "... um broche engraçado, uma sereia dourada. [...] a nórdica mãe d'água,Yemanjá de Estocolmo" (AMADO, p.362) que marcará o reinício de sua relação de amor com Nacib, já ao fim do romance, depois do casamento entre os dois haver "fracassado".

Através do casamento, Nacib acreditara estar elevando Gabriela ao mais alto grau de status social reservado às mulheres naquela sociedade, mas este lugar pressupunha a aquiescência às novas regras sociais a serem cumpridas no papel de esposa. Mais de uma vez, encontramos, no romance amadiano, a distinção posta pela questão de gênero nas regras para o comportamento feminino associadas também às diferenças de classe social.

Nacib, como esposo, exerce o controle social sobre o comportamento feminino para que a ordem dos modelos sociais seja preservada. Aquilo que antes Gabriela podia, depois do casamento, não pode mais, não pode ir ao circo, não pode rir alto, usar flor no cabelo, ficar sem sapatos. "Tudo quanto 
A construção da subjetividade feminina brasileira em Gabriela, cravo e canela ...

Gabriela amava, ah! Era proibido a senhora Saad. Tudo quanto a senhora Saad devia fazer, ah! Essas coisas Gabriela não as tolerava." (p.294)

Entretanto, desde logo temos antecipado na cantiga, o pedido do trovador para que o enamorado deixe que Gabriela seja aquilo que é, que não queira transformá-la, que devolva a ela sua condição primeira, com todas as implicações que este lugar traz para sua existência no contexto do sistema político-social ali representado: Manda-a de volta ao fogão/ a seu quintal de goiabas/ a seu dançar marinheiro/a seu vestido de chita/ a suas verdes chinelas/a seu inocente pensar (...)

Depois da descoberta da traição de Gabriela por Nacib, anula-se o casamento entre eles, com base na inexistência oficial de Gabriela. Gabriela nunca tivera documentos e em virtude de terem falsificado um para o casamento, de acordo com o código civil, houvera "erro essencial de pessoa". E desse modo, a mulata é realocada para a margem de onde, inicialmente, viera. A anulação do casamento tem o efeito de devolver Gabriela ao lugar inominado, num espaço entre uma identidade e outra, Gabriela, ao final, não é a amante, nem a cozinheira, nem a rapariga, nem a esposa, sendo ao mesmo tempo tudo isso, deslocando-se nas alteridades de um eterno vir a ser, escapa a qualquer tentativa de um aprisionamento subjetivo universal, a qualquer tentativa de lhe imporem um significado essencializado por excelência e, assim, configura-se nesta, e não noutra, representação de mulher.

Como bem aponta Constância Lima Duarte (2004, p.166), se tomamos gênero no sentido de Lauretis como "a representação de cada indivíduo em termos de uma relação social preexistente ao próprio indivíduo e predicada sobre a oposição 'conceitual'e rígida (estrutural) dos dois sexos biológicos", (LAURETIS, 1994, p.211) podemos concluir que o romance Gabriela, cravo e canela de Jorge Amado pode ser lido como representante tanto da construção subjetiva feminina quanto de sua construção social.

No presente trabalho, procuramos explorar as representações de gênero das personagens femininas que se destacam no romance Gabriela, cravo e canela dando nome aos quatro capítulos da obra e estruturando-a de modo que pudemos lê-la como o legado literário de Jorge Amado que, através do percurso enunciado de Ofenísia à Gabriela, passando por Glória e Malvina, representou o trajeto percorrido pelas mulheres brasileiras através dos deslocamentos identitários que as constituíram, tendo sido produzidos sob o discurso hegemônico do patriarcado ao longo do período entre o final do séc. XIX e o início do séc. XX. 
Para essa leitura, enfatizamos as epígrafes musicais que abrem os capítulos nos referenciando, principalmente, nas teorias da crítica feminista e de gênero, bem como, na crítica sociológica e nas contribuições dos estudos culturais, entretanto, sem a preocupação de privilegiarmos nenhum desses movimentos em particular e com a certeza de que deixamos para trás muitas outras leituras possíveis dessas representatividades.

\section{Referências}

ABDALA JUNIOR, Benjamin. Dona Flor, um produto de exportação. In: Fronteiras múltiplas, identidades plurais: um ensaio sobre mestiçagem e hibridismo cultural. São Paulo: Senac, 2002.

AMADO, Jorge. Gabriela, cravo e canela. Rio de Janeiro: Record/Altaya, 19--. (Mestres da Literatura Contemporânea)

ARAÚJO, Emanuel. A arte da sedução: sexualidade feminina na colônia. In: DEL PRIORE, Mary. História das mulheres no Brasil. 3. ed. São Paulo: Contexto, 2000, p. 59.

BAKHTIN, Mikhail. Estética da criação verbal. São Paulo: Martins Fontes, 1992.

BOURDIEU, Pierre. A dominação masculina. 4. ed. Rio de Janeiro: Bertrand Brasil, 2005.

BUTLER, Judith. Problemas de gênero: feminismo e subversão da identidade. Rio de Janeiro: Civilização Brasileira, 2003.

CANDIDO, Antonio. Literatura e sociedade. 8. ed. São Paulo: PubliFolha, 2000. (Grandes Nomes do Pensamento Brasileiro)

DEL PRIORE, Mary (Org.). História das mulheres. São Paulo: Contexto, 2000.

DUARTE, Constância Lima. As relações sociais de gênero em Gabriela, cravo e canela, de Jorge Amado. In: OLIVIERI-GODET, Rita; PENJON, Jacqueline (Orgs.). Jorge Amado: leituras e diálogos em torno de uma obra. Salvador-Bahia: Casa da Palavra, 2004.

DUARTE, Eduardo de Assis. Aquarelas do Brasil: Margens da identidade nacional na ficção de Jorge Amado. In: CHIAPPINI, Ligia; BRESCIANI, Maria Stella. Literatura e cultura no Brasil: identidades e fronteiras. São Paulo: Cortez, 2002.

FREYRE, Gilberto. Sobrados e mucambos: decadência do patriarcado e desenvolvimento do urbano. 16. ed. São Paulo: Global, 2006.

GALLOP, Jane. Reading the mother tongue: psychoanalytic feminist criticism. Critical Inquiry, inverno 1987.

HALL, Stuart. Identidade cultural na pós-modernidade. DP\&A Editora, 2006.

HOLLANDA, Heloísa Buarque de (Org.) Tendências e impasses: o feminismo como crítica da cultura. Rio de Janeiro: Rocco, 1994. 
A construção da subjetividade feminina brasileira em Gabriela, cravo e canela ...

JAUSS, H. R. A história da literatura como provocação à teoria literária. São Paulo: Ática, 1994

LAURETIS, Teresa de. A tecnologia de gênero. In: HOLLANDA, Heloísa Buarque de (Org.). Tendências e impasses: o feminismo como crítica da cultura. Rio de Janeiro: Rocco, 1994.

MISKOLCI, Richard; CARVALHO, Sheila Abadia Rocha. “A 'Tal' e a 'Qual': representações racializadas da mulher na literatura brasileira". In: SEMINÁRIO INTERNACIONAL FAZENDO GÊNERO 7, 2006, Florianópolis. Anais... Florianópolis: IEG, 2006b. Disponível em: $<$ http://www.fazendogenero7.ufsc.br/artigos/M/Miskolci-Carvalho_13_B.pdf>. Acesso em: 29 ago. 2009. MOISÉS, Massaud. Dicionário de termos literários. São Paulo: Cultrix, 2004.

SILVA, Maria Beatriz Nizza da. Mulheres brancas no fim do período colonial. Disponível em: <http://www.unicamp.br/pagu/cadernos4.html>. Acesso em: 29 ago. 2009.

VALLEJOS, A.; YANNOULAS, Silvia; LENARDUZZI, Zulma. Lineamientos epistemológicos. Disponível em: <http://bibliotecavirtual..clacso.org.ar/ar/libros/brasil/flacso/linea pdf> Acesso em: 29 ago. 2009.

VEIGA, Benedito. Gabriela, cravo e canela: a recepção crítica. Disponível em: <HTTP:// www.filologia.org.br/viicnlf/anais/caderno09-12.html>. Acesso em: 15 junho 2009.

WOLLSTONECRAFT, Mary. A vindication of the rights of woman with strictures on political and moral subjects. Disponível em: $<$ http://www.bartleby.com/144/>. Acesso em: 15 junho 2009 .

Recebido para publicação em 02 de julho de 2009. Aceito para publicação em 08 de março de 2010. 